\title{
WHY THE DECOLONISATION OF HIGHER EDUCATION WITHOUT CRITIQUE IS NOT POSSIBLE?
}

\author{
Y. Waghid \\ Department of Education Policy Studies \\ Stellenbosch University \\ Stellenbosch, South Africa \\ e-mail: yw@sun.ac.za / https://orcid.org/0000-0003-2565-824X
}

\section{ABSTRACT}

Undeniably the decolonisation of higher education on the African continent (Waghid 2007; Waghid, Waghid, and Waghid 2018) is a tenuous academic pursuit considering its entanglement with complexities, paradoxes and tensions (Zembylas 2018). However, I do not wish to argue against the importance of decolonisation of higher education but instead use the notion of critique (decentring of the self) as an instance as to how and why higher education discourses in African universities are in dire need to decolonise.

Keywords: De-colonisation, higher education, decentring, critique

\section{ON A RATIONALE FOR THE DECOLONISATION OF HIGHER EDUCATION}

If one were to conceive of decolonisation as an elusive term (Zembylas 2018), it seems more apt to look at what colonialism actually entails. On the one hand, colonialism seems to be linked to the exercise of politico-economic sovereignty of one dominant nation over another less dominant one (Maldonado-Torres 2007). On the other hand, coloniality can be considered as the degradation of the cultural values, economic aspirations, and knowledge interests of colonised communities (Mbembe 2016). By implication, the decolonisation of higher education can be considered as an attempt to resolve the imperialist legacy of both colonialism and coloniality. How does one remedy the debilitating conditions of colonialism and coloniality? Perhaps in response to the latter question, the claim that decolonisation is an elusive term seems justifiable on the grounds that decolonising higher education - the usual response - seems to be as evasive as the term is faulted. Consequently, I want to insert the notion of critique into the debate on the grounds that, like decolonisation, the practice of critique seems to be linguistically and pragmatically embedded in a decentring of the self. Drawing on the seminal thoughts of Marianna Papastephanou $(2015,200)$, a decentring of the self involves restraining the self within the collectivity and simultaneously restraining the collective self with regard to 
its aspirations against what lies outside the collectivity. Although Papastephanou (2015) develops this idea of decentring the self in relation to her notion of an eccentric cosmopolitanism, what attracts me to this notion of decentring the self is that the self is at once called upon to reconsider critically the impact of her priorities and values on others and otherness (Papastephanou 2015, 2). Decentring the self is in fact an ethico-political demand that otherness makes on the self through a discourse of (higher) education (Papastephanou 2015, 1).

In light of decentring the self - a poststructuralist form of critique - I want to offer three ways in which such a decentred self can contribute to advancing the decolonisation of higher education in Africa. Firstly, decolonisation of higher education through the agency of a decentralised self implies that the self restrains her own advocacy for knowledge interests that prioritise predominantly the self. Put more simplistically, the self curbs her own prioritisation and valorisation of knowledge considered as important to the self. It is not as if knowledge produced locally is of no relevance to higher education but rather that such knowledge is reprioritised in relation to what is other and different. That is, knowledge considered as important to the self is not prioritised at the expense of what is "western", other and different. When the self is decentred she develops a conception of knowledge that is reconsidered in light of the collective so that knowledge appears as less compartmentalised in the form of indigenous juxtaposed against non-indigenous or western knowledge.

Secondly, knowledge production that prioritises the collective is often based on a skewed understanding that knowledge ought to be produced only in a collectivity and that such a form of knowledge is ultimately quite distinctive and dominant. Major thinkers such as Plato, Socrates and Pythagoras could hardly be considered as thinkers in a collectivity. Decentring of the self shifts the focus away from knowledge production in the collective and that knowledge production should only be about the collective. Such an understanding of knowledge production would invariably undermine the autonomy of the self in the sense that the self does not exclusively require a collectivity to advance knowledge production.

Thirdly, decentring the self is an ethico-political demand for the recognition of otherness. Here, other knowledge can be construed as knowledge that does not exclusively advance a particular value system or tradition but rather exists as fused knowledge on the basis of what is indigenous or local is brought into synthesis with western or non-western hegemonic forms of knowledge. Pioritising what should be considered as African against "western", canononisation or standardisation of knowledge against the devaluation of African knowledges, and the validation of what can be considered as an African worldview of knowledge against nonAfrican cultural and traditional thought should not be used to justify either a Eurocentric or Afrocentric approach to knowledge production. Rather, to become ethically and politically 
responsive to knowledge production in Africa should not involve taking the risk of eliminating racially biased Eurocentric patterns of knowledge production in African higher education (Ndlovu-Gatsheni 2015). Instead, decolonisation of higher education in the frame of a decentring of the self is ethically and politically motivated to integrate multiple knowledge systems along the lines decolonisation so that Afro-centric and Euro-centric approaches to knowledge are reconstituted towards the cultivation of knowledge about otherness.

Finally, what decentring the self foregrounds is that knowledge of any kind should be about integration and validation and not about prioritising knowledge within a collective and beyond. When knowledge is produced on the basis of decentring the self - a metaphor for ethico-political change - the chances of decolonising of higher education would hopefully be enhanced.

\section{REFERENCES}

Maldonado-Torres, N. 2007. On the coloniality of being: Contributions to the development of a concept. Cultural Studies 21(2-3): 240-270.

Mbembe, A. J. 2016. Decolonizing the university: New directions. Arts and Humanities Education 15(1): 29-45.

Ndlovu-Gatsheni, S. 2015. Genealogies of coloniality and implications for Africa's development. Africa Development XL(3): 13-40, L(3): 13-40.

Papastephanou, M. 2015. Thinking differently about cosmopolitanism: Theory, eccentricity, and the globalised world. Boulder \& London: Paradigm Publishers.

Waghid, Y. 2007. "Education, responsibility and democratic justice: Cultivating friendship to alleviate some of the injustices on the African continent." Educational Philosophy and Theory 39(2): 182196.

Waghid, Y., F. Waghid, and Z. Waghid. 2018. Rupturing African philosophy on teaching and learning: Ubuntu justice and education. New York: Palgrave-MacMillan.

Zembylas, M. 2018. Decolonial possibilities in South African higher education: Reconfiguring humanizing pedagogies as/with decolonial pedagogies. South African Journal of Education 38(4): $1-11$. 